\title{
Gadolinium-ethoxybenzyl-diethylenetriamine (Gd-EOB-DTPA)- enhanced magnetic resonance imaging with various enhancement ratios: a correlation with clinical assessment of liver function using the Child-Pugh scoring system
}

\author{
Zastosowanie rezonansu magnetycznego z hepatotropowym środkiem \\ kontrastowym (Gd-EOB-DTPA - kwas gadoksetowy) w ocenie funkcji wątroby \\ u pacjentów z marskością - korelacja ze skalą Childa-Pugha \\ Łukasz Wypchło ${ }^{1}$, Jakub Jaskólski², Dorota Zarębska-Michaluk ${ }^{3}$, Ewa Stochmal ${ }^{1}$, Piotr Stępień ${ }^{3}$, \\ Andrzej Cieszanowski
}

\author{
${ }^{1}$ Department of Diagnostic Imaging, Jan Kochanowski University, Kielce, Poland \\ Head of the Department: Łukasz Wypchło MD \\ ${ }^{2}$ Department of Diagnostic Imaging, Voivodeship Hospital, Kielce, Poland \\ Head of the Department: Łukasz Wypchło MD \\ ${ }^{3}$ Department of Infectious Diseases, Jan Kochanowski University, Kielce, Poland \\ Head of the Department: Pawet Pabjan MD \\ ${ }^{4}$ Department of Clinical Radiology, Medical University of Warsaw, Warsaw, Poland \\ Head of the Department: Prof. Marek Gołębiowski MD, PhD
}

Key words: liver cirrhosis, Gd-EOB-DTPA, Child-Pugh score, gadoxetate disodium, contrast enhancement ratio.

Słowa kluczowe: marskość wątroby, Gd-EOB-DTPA, skala Childa-Pugha, kwas gadoksetowy, contrast enhancement ratio.

\begin{abstract}
Introduction: Liver cirrhosis has been becoming a major cause of mortality in developed countries. Recently, the increasing role of magnetic resonance imaging (MRI) in the diagnosis of liver cirrhosis has been emphasized. For grading of liver fibrosis, various quantitative parameters have been proposed, such as contrast enhancement index (CEI), contrast enhancement ratio (CER), liver-to-muscle ratio (LMR) and liver-to-spleen ratio (LSR). Their role in the assessment of the liver function has not yet been thoroughly investigated.

Aim of the research: To determine whether there is a correlation between hepatocyte-specific contrast-enhanced MRI and liver function impairment classified by the Child-Pugh scoring system in patients with cirrhosis thirty two.

Material and methods: Ninety four patients with cirrhosis and thirty two patients with clinically healthy liver who underwent gadolinium ethoxybenzyl-diethylenetriaminepentaacetic acid (Gd-EOB-DTPA)-enhanced MR imaging were enrolled in this study. Patients from the study group were divided into three subgroups according to the Child-Pugh scoring system. The values of all four enhancement ratios (CEI, CER, LMR and LSR) were compared between groups.

Results: The mean values of all four parameters were significantly lower in patients with moderate or severe liver function impairment (Child-Pugh B and Child-Pugh C) than in patients with mild impairment (Child-Pugh A). Amongst all parameters, CER and LMR showed the best correlation with liver function impairment ( $r=-0.57$ and $r=-0.58$, respectively). Conclusions: Our study showed a good correlation between quantitative evaluation of the liver function using Gd-EOBDTPA MR imaging and clinical assessment in patients with cirrhosis.
\end{abstract}

\section{Streszczenie}

Wprowadzenie: Marskość wątroby będąca zejściem wielu przewlekłych chorób tego narządu jest jedną z głównych przyczyn śmiertelności w krajach rozwiniętych. Biopsja wątroby uważana za złoty standard w rozpoznawaniu marskości wiąże się z wieloma powikłaniami, dlatego ostatnio podkreśla się rosnącą rolę rezonansu magnetycznego (MRI) w diagnostyce marskości.

Cel pracy: Określenie skuteczności MRI wątroby wzmocnionego Gd-EOB-DTPA (kwas gadoksetowy) w ocenie jej funkcji u pacjentów z marskością w odniesieniu do klinicznej skali Childa-Pugha.

Materiał i metody: Do badania włączono 126 pacjentów, u których w latach 2013-2016 wykonano MRI wątroby z hepatotropowym środkiem kontrastującym. Grupa badana składała się z 94 pacjentów z klinicznie rozpoznaną marskością, 
których podzielono na 3 podgrupy, w zależności od stopnia ciężkości uszkodzenia wątroby, używając do tego skali Childa-Pugha. Grupę kontrolną stanowiło 32 pacjentów bez klinicznych wykładników marskości. Następnie dokonano analizy badań MRI wątroby z obliczeniem parametrów określających stopień wzmocnienia pokontrastowego - contrast enhancement index (CEI), contrast enhancement ratio (CER), liver-to-muscle ratio (LMR) i liver-to-spleen ratio (LSR).

Wyniki: Średnie wartości wszystkich czterech parametrów były istotnie niższe u pacjentów z umiarkowanym lub ciężkim uszkodzeniem czynności wątroby (klasa B i C wg skali Childa-Pugha) niż u pacjentów z łagodnym uszkodzeniem (klasa A wg skali Childa-Pugha). Spośród wszystkich ocenianych parametrów wzmocnienia CER oraz LMR wykazały najwyższą korelację ze stopniem uszkodzenia wątroby na podstawie skali Childa-Pugha $(r=-0,57$ i $r=-0,58)$, natomiast najsłabszą korelację zaobserwowano dla LSR $(r=-0,22)$.

Wnioski: Rezonans magnetyczny wątroby z hepatotropowym środkiem kontrastowym może być dobrym narzędziem klinicznym do nieinwazyjnej oceny funkcji wątroby u pacjentów z marskością.

\section{Introduction}

Liver cirrhosis is the final pathological result of many chronic liver diseases and an increasing cause of mortality in developed countries [1, 2]. Fibrosis which precedes cirrhosis is characterized by an increase in the number of fibroblasts and accumulation of collagen fibers resulting in progressive loss of hepatocytes and liver function impairment [3]. Liver biopsy, called "the gold standard" for liver fibrosis assessment, is invasive and carries a risk of complications and sampling errors [4-6], including a small tissue sample, inter-and intraobserver variability and post-procedure complications such as pain and bleeding, resulting in an overall low cost-effectiveness ratio [7, 8]. Over time it has become evident that this reference technique is inaccurate. Less invasive methods that would be safer, better tolerated by the patient and could be repeated as often as required have become more desirable $[9,10]$.

Recently, the increasing role of magnetic resonance imaging (MRI) in the diagnosis of liver cirrhosis has been emphasized. The most promising techniques are diffusion-weighted imaging (DWI), contrast enhancement (CE) MRI indexes utilizing hepatobiliary contrast agents and magnetic resonance elastography (MRE) [11-13].

DWI can evaluate restricted diffusion in cirrhotic liver caused by excessive accumulation of extracellular matrix, however susceptibility to motion artifacts and poor signal-to-noise ratio due to high $b$ values used in this method are considered to be major limitations [14-16]. Several groups of investigators have reported that hepatocyte-specific contrast-enhanced MR imaging (Gd-EOB-DTPA-enhanced MRI) can be used for staging of liver fibrosis. Approximately 50\% of GdEOB-DTPA is taken up by hepatocytes and excreted with bile; the more hepatocytes, the greater the uptake of the contrast agent, and thus the greater contrast enhancement of functional liver parenchyma in hepatobiliary phase [17]. For grading of liver fibrosis, different quantitative parameters have been utilized, including the contrast enhancement ratio (CER), contrast enhancement index (CEI), liver-to-muscle ratio (LMR), liver-to-spleen ratio (LSR), and liver-to-intervertebral disc SI ratio (LI) [17-20], however their usefulness has not yet been thoroughly investigated [21-24].
The potential advantage of parameters related to Gd-EOB-DTPA liver imaging over non-contrast enhanced indexes, including DWI derived apparent diffusion coefficient (ADC) values, is that they are not affected by deposition of fat and iron, as well as perfusion effect from blood vessels. Moreover, the use of Gd-EOB-DTPA-enhanced MRI provides not only morphological information but enables evaluation of the liver function, focal hepatic lesions and bile duct obstruction [25].

The Child-Pugh (CP) scoring system was originally designed to predict mortality in patients with cirrhosis. Based upon five clinical and laboratory criteria: ascites, neurological disorder, serum bilirubin, serum albumin and prothrombin time, patients are divided into three categories: A - good hepatic function, $\mathrm{B}$ - moderately impaired hepatic function, and $\mathrm{C}$ - advanced hepatic dysfunction [26, 27]. It has a major clinical importance as it enables to assess the prognosis, helps in choosing optimal treatment and predicting the expected survival rate in these patients. To date there have been only a few publications discussing the association between functional Gd-EOB-DTPAenhanced MRI and the Child-Pugh scoring system in the assessment of patients with liver fibrosis [28-30].

\section{Aim of the research}

The purpose of this study was to determine the efficacy of quantitative Gd-EOB-DTPA-enhanced MRI for assessing the liver function impairment in cirrhotic patients in correlation with the clinical assessment using the Child-Pugh scoring system.

\section{Material and methods}

\section{Patients}

Our retrospective study was approved by the local institutional review board. We researched and selected 332 patients who underwent hepatocyte-specific contrast-enhanced MRI in our department in 20132016, on account of evaluation of chronic liver disease or a suspected focal liver lesion. The inclusion criteria for the control group were as follows: clinically healthy liver, no history of chronic liver disease nor liver cirrhosis. The factor that determined allocation 
to the study group was clinically diagnosed cirrhosis. The exclusion criteria were incomplete data and MRI study without Gd-EOB-DTPA. Finally, 126 patients were enrolled in this study (94 in the study group and 32 in the control group).

The study group $(n=94)$ comprised patients with cirrhosis and the most common underlying disease was chronic hepatitis C (VHC). The classes of the diagnosis of liver disease in the study group are listed in Table 1. The mean age in this group was $60.4 \pm 12.63$ years, median 60 (55-69) years (Figure 1).

Thirty-two patients without liver cirrhosis comprised the control group. The most common underlying disease was a benign, clinically insignificant focal liver lesion (Table 2). The mean age in this group was 52.2 \pm 15.52 years, median 51 (39.5-62.5) years (Figure 2 ).

In the study group the diagnosis of cirrhosis was made using standard abdominal ultrasound and clinical findings: presence of ascites, gastroesophageal varices, icterus and hepatic encephalopathy. Based on the Child-Pugh scoring system these patients were subsequently divided into 3 subgroups, according to the severity of liver function impairment. Subgroup A (CP-A, $n=62$ ) comprised patients with 6 points or less in the 15-point Child-Pugh scale, subgroup B (CP-B, $n=21)$ patients with 7-9 points and subgroup C (CP-C, $n=11$ ) patients with 10 points or more (Figure 3 ). Furthermore to assess the possible impact of biochemical parameters on contrast enhancement ratio values, laboratory blood tests were performed in all patients, including following serum parameters: bilirubin, alanine transaminase (ALT), aspartate transaminase (AST), $\gamma$-glutamyl transpeptidase (GGT), alkaline phosphatase (ALP), serum albumin, hemoglobin, thrombocytes and creatinine.

\section{MRI technique and evaluation}

MRI was performed with a 1.5 Tesla (T) MRI scanner using phased-array multicoil system. For the acquisition of hepatobiliary phase images we used the generalized autocalibration partially parallel acquisition (GRAPPA) algorithm with volumetric interpolated breath-hold examination (VIBE). The parameters of T1 VIBE sequence were consistent with our standard abdominal scanning protocol: TR $2.97 \mathrm{~ms}$, TE $1.1 \mathrm{~ms}$, average 1, voxel size 1.9 $\times 1.4 \times 1.8 \mathrm{~mm}$, slice thickness $1.8 \mathrm{~mm}$, flip angle 10 deg., and phase oversampling 30\%.

Besides the hepatobiliary phase, the imaging protocol consisted of the following sequences: axial breath-hold T2-weighted TSE sequence, axial and coronal respiratory-triggered T2-weighted TSE sequence with fat-saturation, axial breath-hold in-and-out-ofphase spoiled gradient echo sequence with double echo, coronal trueFISP sequence and axial T1 VIBE sequence for dynamic contrast-enhanced images.

The dynamic study and hepatobiliary phase images were obtained after an intravenous administration
Table 1. Diagnosis of the disease in the study group

\begin{tabular}{|lcc|}
\hline Diagnosis & Number & $\%$ \\
Viral hepatitis C & 62 & 66 \\
Viral hepatitis B & 10 & 11 \\
Alcohol liver disease & 16 & 17 \\
Primary biliary cirrhosis & 4 & 4 \\
Other & 2 & 2 \\
Total & 94 & 100 \\
\hline
\end{tabular}

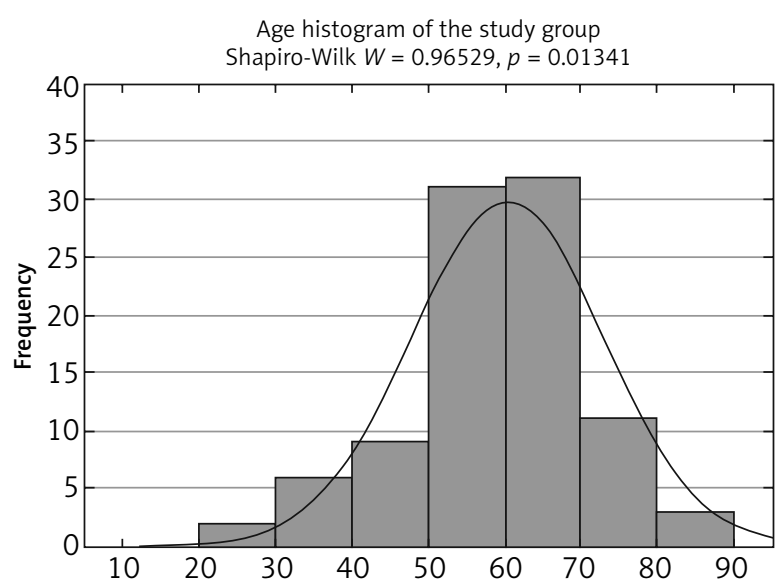

Figure 1. Age histogram of the study group

Table 2. Diagnosis of the disease in the control group

\begin{tabular}{|lcc|}
\hline Diagnosis & Number & $\%$ \\
Hepatic hemangioma & 5 & 16 \\
Liver cyst & 9 & 28 \\
Constipation & 1 & 3 \\
Hydatid cyst & 1 & 3 \\
Liver steatosis & 5 & 16 \\
Focal nodular hyperplasia (FNH) & 2 & 6 \\
Choledocholithiasis & 1 & 3 \\
Other & 7 & 22 \\
Biliary cysts & 1 & 3 \\
Total & 32 & 100 \\
\hline
\end{tabular}

of gadoxetic acid disodium (Gd-EOB-DTPA) followed by a $20 \mathrm{ml}$ saline infusion. The contrast medium was injected at a dose of $0.025 \mathrm{mmol} / \mathrm{kg}$ body weight. Hepatobiliary phase images were acquired at $20 \mathrm{~min}$ after the contrast injection in axial and coronal planes.

\section{Analysis of MRI}

All signal intensity (SI) measurements were made on a standard workstation, by placing a $1 \mathrm{~cm}^{2}$ circular 


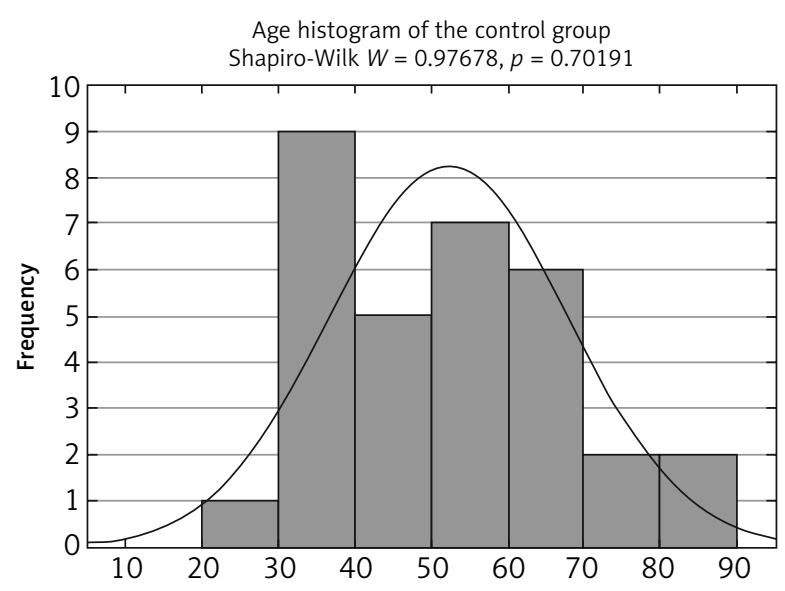

Figure 2. Age histogram of the control group

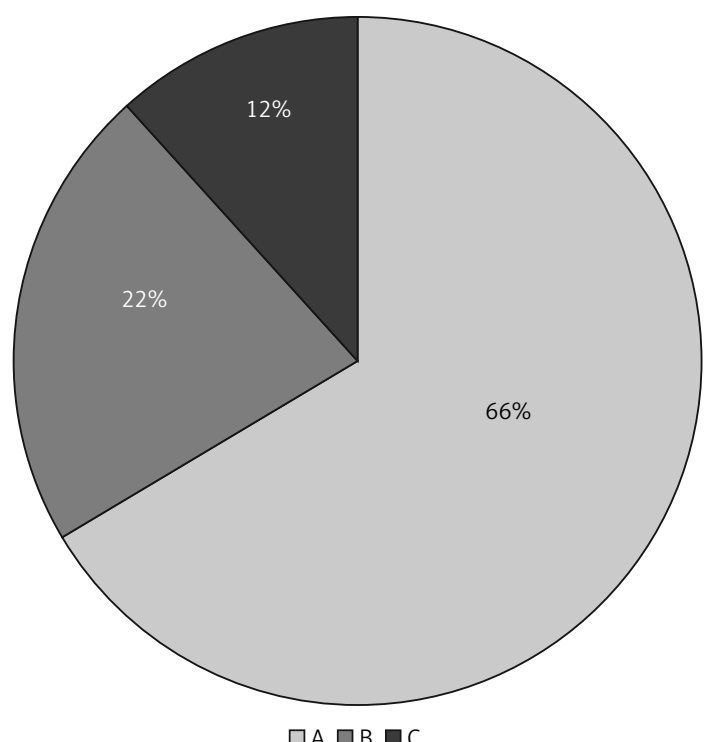

Figure 3 . The pie chart of patients from the study group divided according to the Child-Pugh scale
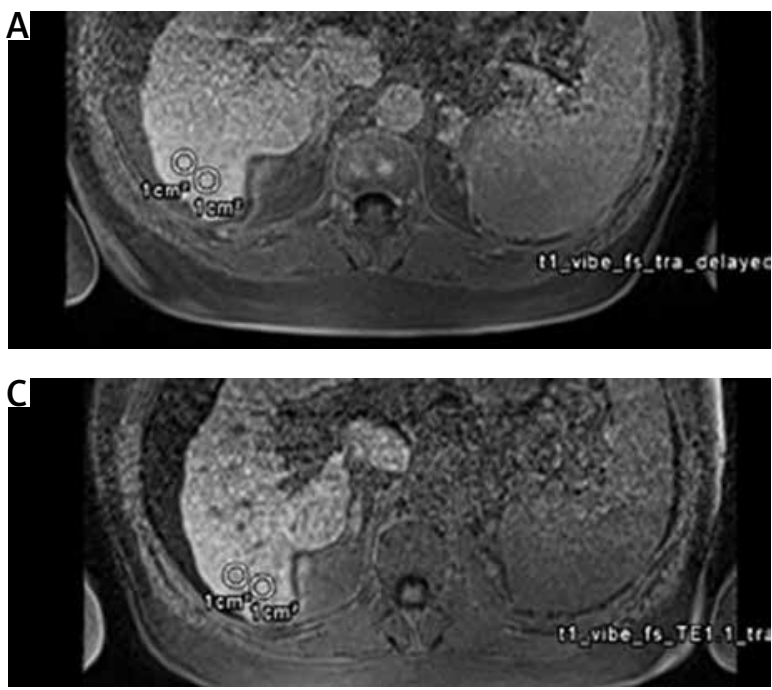

region of interest (ROI) on liver, muscle and spleen parenchyma, avoiding large blood vessels, liver capsule and areas of fatty infiltrations of paraspinal muscles, possibly at the same slice on pre-enhanced and enhanced MR images (Figure 4). Mean SI was used as a datum.

For the purposes of this study, we divided liver into four sections: left lateral section, comprising segments 2 and 3 , left medial section (segments $4 \mathrm{a}$ and $4 \mathrm{~b}$ ), right anterior section (segments 5 and 8) and right posterior section (segments 6 and 7). To obtain pre-liver SI we averaged SI value of 8 measurements ( 2 measurements for each section) on pre-enhanced imaging. The same procedure was repeated on contrast-enhanced imaging to establish liver SI.

The following formulae were used to calculate CER, CEI, LMR and LSR: CER = liver SI/pre-liver SI, $\mathrm{CEI}=$ SIpost/SIpre, where SIpost and SIpre are the liverto-muscle (LMR) signal intensity ratios in the hepatocyte phase and pre-enhanced images, respectively; LMR = liver SI/muscle SI, LSR = liver SI/spleen SI.

Muscle SI was the mean value of 4 SI measurements ( 2 measurements for the right erector spinae muscle and 2 for the left) at the hepatobiliary phase. Spleen SI was the average value of 2 SI measurements at the hepatobiliary phase.

\section{Statistical analysis}

Statistical analysis was performed with Statistica software (version 13.3, StatSoft, Poland). The results are expressed as the mean \pm standard deviation (SD).

$t$-Student, $U$ Mann-Whitney and Cochran-Cox tests were used to evaluate statistical differences between study and control groups. Assessment of the equality of variances and normality in groups was performed with Levene and Shapiro-Wilk tests.

The differences between four groups (control group, Child-Pugh A, B and C) were tested using the one-way ANOVA and the Kruskal-Wallis test.

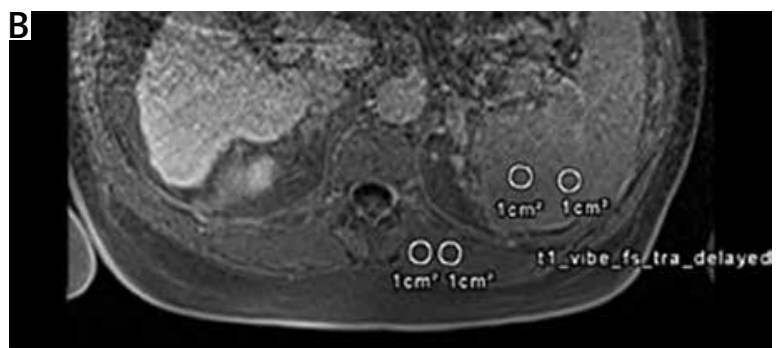

Figure 4. ROIs placement used for CEI, CER, LMR and LSR calculation. ROls were placed avoiding large vessels, liver and spleen capsule and muscle fatty infiltrations 
Table 3. Mean CEI, CER, LMR and LSR values for different stages of liver function impairment. The results are expressed as the mean \pm SD. The values of each parameter decreased as the degree of liver function impairment increased

\begin{tabular}{|lcccc|}
\hline Stage of liver function impairment & CEI & CER & LMR & LSR \\
Control group & $1.46 \pm 0.292$ & $1.63 \pm 0.178$ & $0.97 \pm 0.225$ & $1.30 \pm 0.408$ \\
Mild (Child-Pugh A) & $1.32 \pm 0.201$ & $1.51 \pm 0.172$ & $0.74 \pm 0.181$ & $1.27 \pm 0.304$ \\
Moderate (Child-Pugh B) & $1.19 \pm 0.152$ & $1.38 \pm 0.116$ & $0.64 \pm 0.091$ & $1.18 \pm 0.206$ \\
Severe (Child-Pugh C) & $1.15 \pm 0.132$ & $1.24 \pm 0.119$ & $0.54 \pm 0.121$ & $0.97 \pm 0.212$ \\
Study group (Child-Pugh A + B + C) & $1.27 \pm 0.198$ & $1.45 \pm 0.181$ & $0.69 \pm 0.172$ & $1.22 \pm 0.289$ \\
\hline
\end{tabular}

To indicate exactly which averages are different from each other, Turkey's and Dunn's post-hoc tests were performed.

In order to determine the possible relationship between CER and serum liver function tests, multiple regression analysis was performed.

\section{Results}

The mean and median values of the CEI, CER, LMR and LSR parameters in each group are listed in Table 3.

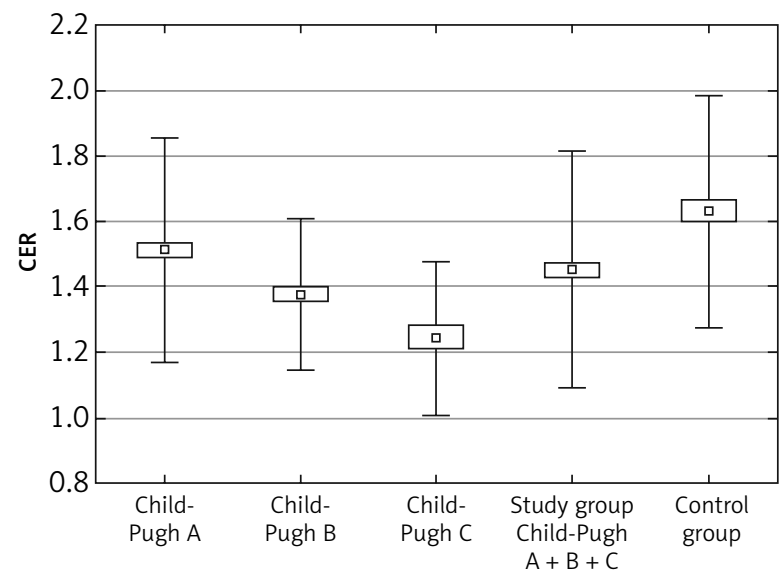

Figure 5. Distribution of the CER values (mean, mean $\pm S D$, mean $\pm 1.96 \times \mathrm{SD})$

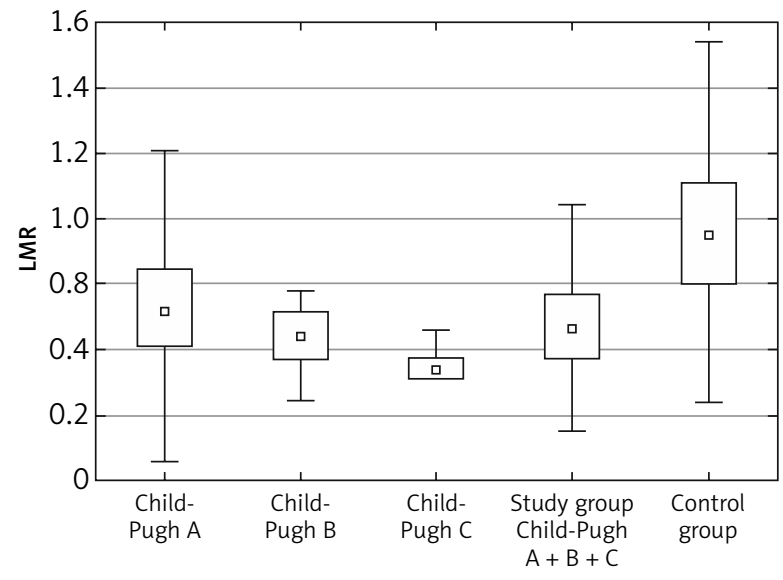

Figure 7. Distribution of the LMR values (median, $25-75 \%$; non-outlier range)
The graphic representation of distribution of CER, CEI, LMR and LSR values in patients with different liver function is shown in Figures 5-9.

Patients from the control group presented a significantly higher CER, CEI and LMR level compared to the study group (Child-Pugh $\mathrm{A}+\mathrm{B}+\mathrm{C}$ ) with $p=0.0000003$, $p=0.0019$ and $p<<0.0001$, respectively. There was no significant difference in LSR values between the control group and the study group ( $p=0.303159$ ).

The values of all four parameters were significantly lower in patients with moderate or severe liver

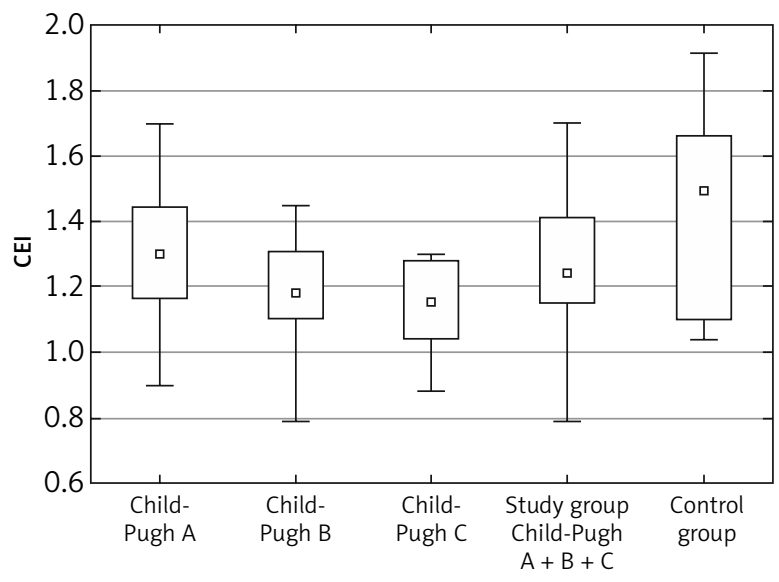

Figure 6. Distribution of the CEI values (median, $25-75 \%$; non-outlier range)

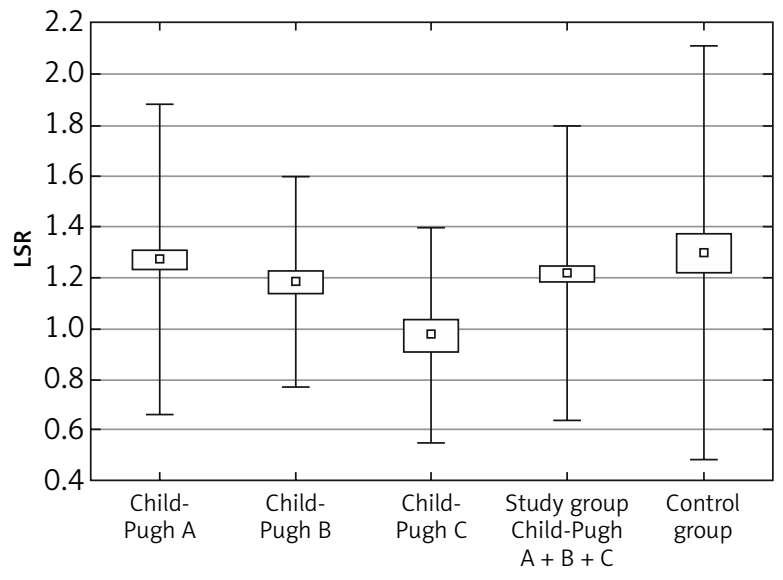

Figure 8. Distribution of the LSR values (mean, mean $\pm S D$, mean $\pm 1.96 \times \mathrm{SD}$ ) 

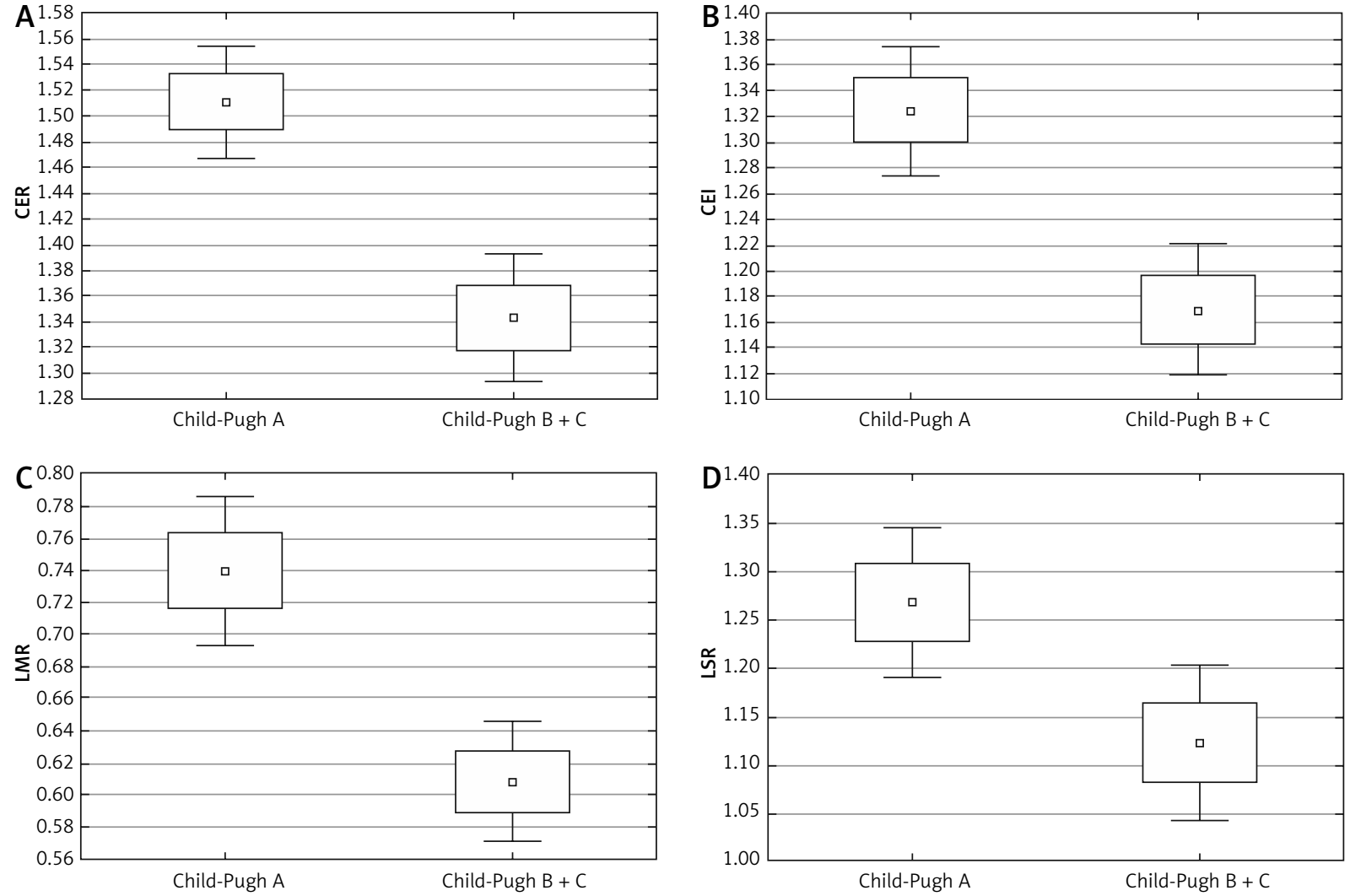

Figure 9. Difference between mild vs. moderate and severe liver function impairment (Child-Pugh A vs. Child-Pugh $B+C$ )

function impairment (CP-B and $\mathrm{CP}-\mathrm{C})$ than in patients with mild impairment (CP-A) (Figure 9).

In order to determine diagnostic performance of all 4 parameters in predicting advanced liver function impairment, receiver operating characteristic (ROC) analysis was performed. CER and LMR showed higher sensitivity and specificity compared to CEI and LSR (CER: sensitivity 0.812, specificity 0.813 , AUROC 0.912; LMR: sensitivity 0.875 , specificity 0.813, AUROC 0.911; CEI: sensitivity 0.813 , specificity 0.688 , AUROC 0.760; LSR: sensitivity 0.875 , specificity 0.813, AUROC 0.654) (Figure 10).

\section{Discussion}

The purpose of our study was to establish whether there is a relationship between hepatocyte-specific contrast-enhanced MR imaging and liver function impairment classified by the Child-Pugh scoring system. We revealed a significant correlation for following enhancement ratios: CER, LMR and CEI, whereas a poor correlation was found for LSR. These findings are in concordance with some previous papers assessing the role of Gd-EOB-DTPA in liver cirrhosis [17, 18, $22,24,25]$. However those studies focused on staging of liver fibrosis in correlation with histopathology results, whereas our study focused on the relationship between enhancement ratios and clinical assessment of liver impairment. Two of four analyzed CE ratios (CER and LMR) were the most strongly correlated with liver function impairment based on the ChildPugh scoring system (Table 4); furthermore amongst all analyzed parameters CER and LMR predicted advanced liver dysfunction ( $\geq \mathrm{CP}-\mathrm{B}$ ) with highest sensitivity ( 0.81 and 0.88 , respectively) and specificity (0.81), with AUROCs of 0.91 .

So far, the most commonly used parameter in GdEOB-DTPA-enhanced MRI for evaluating liver function [20] and staging of liver fibrosis was CEI. Li et al. [20] assumed that this parameter enables the most objective evaluation of the liver fibrosis as it is utilizing SI values from paraspinal muscle parenchyma as a reference values. On the other hand, our study revealed that the role of $\mathrm{CEI}$ in detecting liver function impairment in patients with fibrosis is inferior to other MRI-biomarkers such as CER and LMR, still we cannot exclude that it could be due to different methodology and reference standard we adopted.

We noted significant overlaps in CE values among patients in different Child-Pugh subgroups, however comparison between patients with mild (CP-A) and moderate + severe liver dysfunction $(\mathrm{CP}-\mathrm{B}+\mathrm{CP}-\mathrm{C})$ revealed significant differences for all four parameters. Therefore we presume that MRI CE ratios may be feasible in assessment of patients with advanced liver dysfunction. 
CER

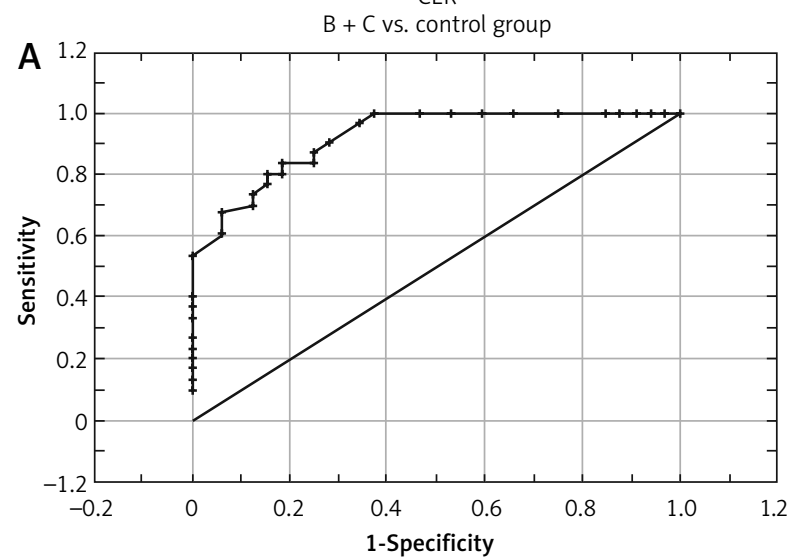

LSR

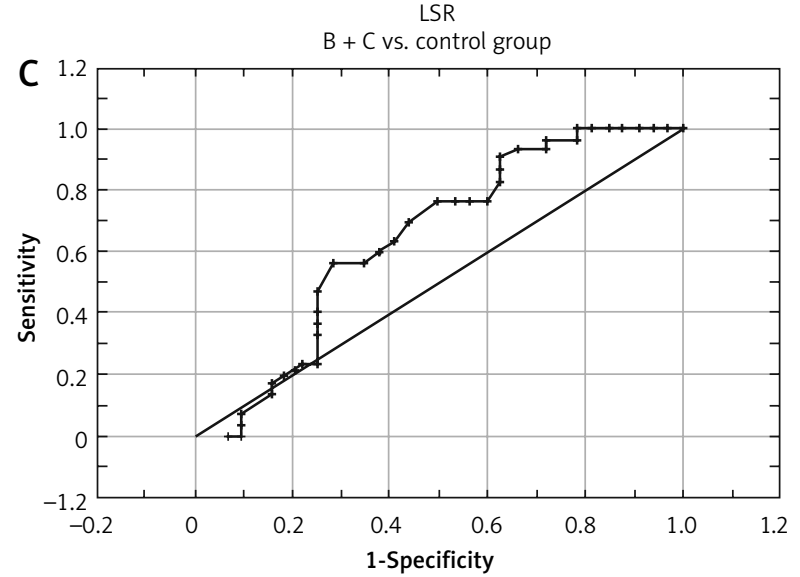

LMR

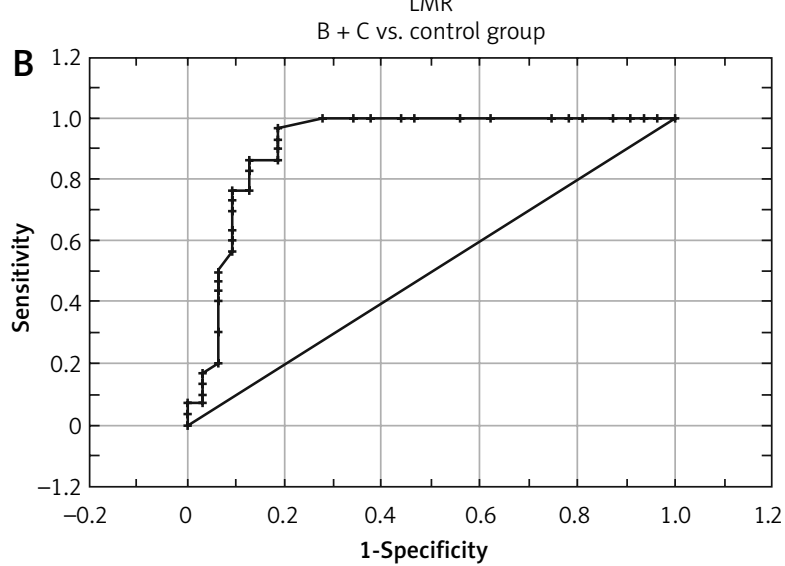

CE

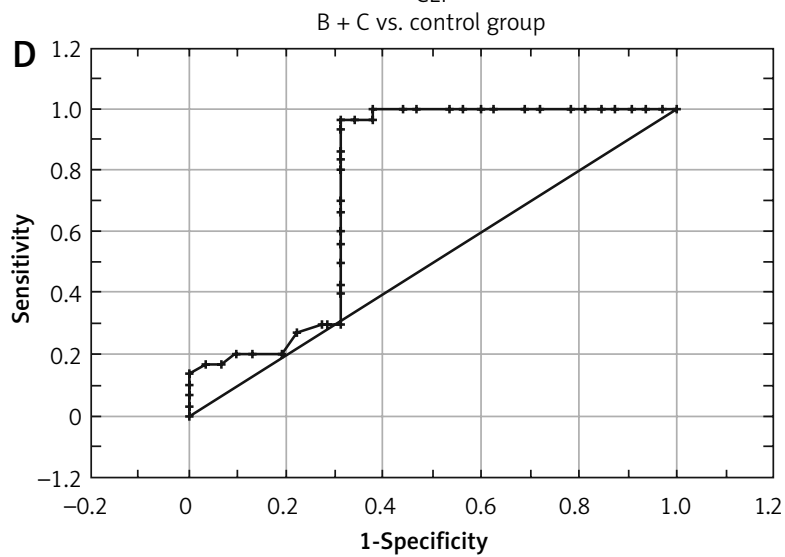

Figure 10. The ROC curves for the diagnostic performance of CER (A), LMR (B), LSR (C) and CEI (D) in predicting moderate or greater ( $\geq$ CP-B vs. control group) liver function impairment

Gadoxetate disodium (Gd-EOB-DTPA) is a hydrophilic, paramagnetic and liver-specific contrast medium, uptaken by hepatocytes with about $50 \%$ of the administered dose secreted by the hepatobiliary pathway [31]. The hepatocyte phase, defined as peak enhancement, is usually reached within $20 \mathrm{~min}$ after the contrast injection in patients with normal hepatic function and lasts for at least $60 \mathrm{~min}$ [32]. Nevertheless, there is a diversity in the methodology and parameters used for hepatocellular contrast-enhanced MRI regarding both acquisition and analysis of images. Chen et al. [33] achieved the best differentiation between no fibrosis and any fibrosis at $10 \mathrm{~min}$ post Gd-EOB-DTPA administration, however most authors support liver assessment at 20 min post injection.

The number of ROIs and their location for SI measurements also differ in various studies. In most studies 1 to 4 ROIs were used to calculate CEI, and no authors relied on the SI measurements only in the left lobe as its lateral segments may be affected by the motion artifacts from the heartbeat, resulting in poor reproducibility of measurements [34]. To decrease this effect we proposed mean value of 8 SI measurements, 2 in each liver section, including both liver lobes.

Changes of liver SI at the hepatobiliary phase are mainly related to the number of functioning hepato-

Table 4. Spearman's rank correlation coefficients for enhancement ratios with liver function based on the Child-Pugh scoring system. A strong indirect relationship was found for CER and LMR

\begin{tabular}{|lccc|}
\hline MR parameter & Correlation coefficient & $P$-value & interpretation of Spearman $\rho$ \\
CER & -0.57 & 0.000 & Strong indirect relationship \\
LMR & -0.58 & 0.000 & Strong indirect relationship \\
CEI & -0.38 & 0.000 & Moderate indirect relationship \\
LSR & -0.22 & 0.014 & Weak indirect relationship \\
\hline
\end{tabular}


Table 5. Results of multiple regression analysis performed in order to assess the impact of blood biochemical parameters on Contrast Enhancement Ratio (CER). Amongst all blood biochemical parameters, only serum bilirubin and albumin were statistically significant, with $p=0.047$ and 0.037 , respectively

\begin{tabular}{|lc|}
\hline Blood biochemical parameter & $P$-value \\
Serum bilirubin & 0.047 \\
Serum albumin & 0.037 \\
ALT & 0.476 \\
AST & 0.524 \\
GGT & 0.053 \\
ALP & 0.093 \\
Hemoglobin & 0.504 \\
Thrombocytes & 0.343 \\
Creatinine & 0.766 \\
\hline
\end{tabular}

Table 6. Percentage share and size of classes in the study group - biopsy, elastography

\begin{tabular}{|lcc|}
\hline Parameter & Number & $\%$ \\
\hline Biopsy: & & \\
\hline No & 89 & 95 \\
\hline F6 & 4 & 4 \\
\hline PBC stage 4 & 1 & 1 \\
\hline Total & 94 & 100 \\
Elastography: & & \\
\hline No & 53 & 56 \\
\hline F4 & 40 & 43 \\
\hline Total & 94 & 100 \\
\hline
\end{tabular}

cytes, but it also appears to be related to several other factors, including the plasma bilirubin level [18]. This fact is consistent with results of our study, showing a relationship of serum bilirubin levels with CER values (Table 5). Furthermore, we found a significant correlation between serum albumin levels and CER.

The major limitations of our study were its retrospective design and lack of correlation of results with liver biopsy (Table 6). In our study group the diagnosis of liver cirrhosis was made clinically. However, this was concordant with the aim of our study, which was correlation of liver function assessed by using hepatospecific contrast enhanced MR imaging with the clinical findings. Other limitation was a small number of CP-B and CP-C patients, which could affect the results.

\section{Conclusions}

Our study showed a good correlation between quantitative evaluation of liver function in cirrhotic patients using Gd-EOB-DTPA MR imaging and clinical assessment. CER and LMR showed the best relationship with the Child-Pugh scoring system amongst all enhancement ratios.

\section{Conflict of interest}

The authors declare no conflict of interest.

\section{References}

1. Zhou WC, Zhang QB, Qiao L. Pathogenesis of liver cirrhosis. World J Gastroenterol 2014; 20: 7312-7324.

2. Tsochatzis EA, Bosch J, Burroughs AK. Liver cirrhosis. Lancet 2014; 383: 1749-1761.

3. Pinheiro D, Dias I, Ribeiro Silva K, Stumbo AC, Thole A, Cortez E, de Carvalho L, Weiskirchen R, Carvalho S. Mechanisms underlying cell therapy in liver fibrosis: an overview. Cells 2019; 8: 1339.

4. Lai M, Afdhal NH. Liver fibrosis determination. Gastroenterol Clin North Am 2019; 48: 281-289.

5. Castera L, Friedrich-Rust M, Loomba R. Noninvasive assessment of liver disease in patients with nonalcoholic fatty liver disease. Gastroenterology 2019; 156: 12641281.e4.

6. Sharma S, Khalili K, Nguyen GC. Non-invasive diagnosis of advanced fibrosis and cirrhosis. World J Gastroenterol 2014; 20: 16820-16830.

7. Lambrecht J, Verhulst S, Mannaerts I, Reynaert H, van Grunsven LA. Prospects in non-invasive assessment of liver fibrosis: liquid biopsy as the future gold standard? Biochim Biophys Acta Mol Basis Dis 2018; 1864: 1024-1036.

8. Potretzke TA, Saling LJ, Middleton WD, Robinson KA. Bleeding complications after percutaneous liver biopsy: do subcapsular lesions pose a higher risk? AJR Am J Roentgenol 2018; 211: 204-210.

9. Lurie Y, Webb M, Cytter-Kuint R, Shteingart S, Lederkremer GZ. Non-invasive diagnosis of liver fibrosis and cirrhosis. World J Gastroenterol 2015; 21: 11567-11583.

10. Sebastiani G, Gkouvatsos K, Pantopoulos K. Chronic hepatitis $C$ and liver fibrosis. World J Gastroenterol 2014; 20: 11033-11053.

11. Bakan AA, Inci E, Bakan S, Gokturk S, Cimilli T. Utility of diffusion-weighted imaging in the evaluation of liver fibrosis. Eur Radiol 2012; 22: 682-687.

12. Nishie A, Asayama Y, Ishigami K, Tajima T, Kakihara D, Nakayama T, Takayama Y, Okamoto D, Taketomi A, Shirabe K, Fujita N, Obara M, Yoshimitsu K, Honda H. MR prediction of liver fibrosis using a liver-specific contrast agent: superparamagnetic iron oxide versus Gd-EOB-DTPA. J Magn Reson Imaging 2012; 36: 664-671.

13. Xiao G, Zhu S, Xiao X, Yan L, Yang J, Wu G. Comparison of laboratory tests, ultrasound, or magnetic resonance elastography to detect fibrosis in patients with nonalcoholic fatty liver disease: a meta-analysis. Hepatology 2017; 66: 1486-1501.

14. Lewin M, Poujol-Robert A, Boëlle PY, Wendum D, Lasnier E, Viallon M, Guéchot J, Hoeffel C, Arrivé L, Tubiana JM, Poupon R. Diffusion-weighted magnetic resonance imaging for the assessment of fibrosis in chronic hepatitis C. Hepatology 2007; 46: 658-665.

15. Taouli B, Tolia AJ, Losada M, Babb JS, Chan ES, Bannan MA, Tobias H. Diffusion-weighted MRI for quantifi- 
cation of liver fibrosis: preliminary experience. AJR Am J Roentgenol 2007; 189: 799-806.

16. Sandrasegaran K, Akisik FM, Lin C, Tahir B, Rajan J, Saxena R, Aisen AM. Value of diffusion-weighted MRI for assessing liver fibrosis and cirrhosis. AJR Am J Roentgenol 2009; 193: 1556-1560.

17. Goshima S, Kanematsu M, Watanabe H, Kondo H, Kawada H, Moriyama N, Bae KT. Gd-EOB-DTPA-enhanced MR imaging: prediction of hepatic fibrosis stages using liver contrast enhancement index and liver-to-spleen volumetric ratio. J Magn Reson Imaging 2012; 36: 1148-1153.

18. Watanabe H, Kanematsu M, Goshima S, Kondo H, Onozuka M, Moriyama N, Bae KT. Staging hepatic fibrosis: comparison of gadoxetate disodium-enhanced and diffusion-weighted MR imaging: preliminary observations. Radiology 2011; 259: 142-150.

19. Lee S, Choi D, Jeong WK. Hepatic enhancement of Gd-EOB-DTPA-enhanced 3 Tesla MR imaging: assessing severity of liver cirrhosis. J Magn Reson Imaging 2016; 44: 1339-1345.

20. Li X, Liu H, Wang R, Yang J, Zhang Y, Li C. Gadoxetate-disodium-enhanced magnetic resonance imaging for liver fibrosis staging: a systematic review and meta-analysis. Clin Radiol 2020; 75: 319.e11-319.e19.

21. Nishie A, Asayama Y, Ishigami K, Tajima T, Kakihara D, Nakayama T, Takayama Y, Okamoto D, Taketomi A, Shirabe K, Fujita N, Obara M, Yoshimitsu K, Honda H. MR prediction of liver fibrosis using a liver-specific contrast agent: superparamagnetic iron oxide versus Gd-EOB-DTPA. J Magn Reson Imaging 2012; 36: 664-671.

22. Harada TL, Saito K, Araki Y, Matsubayashi J, Nagao T, Sugimoto K, Tokuuye K. Prediction of high-stage liver fibrosis using ADC value on diffusion-weighted imaging and quantitative enhancement ratio at the hepatobiliary phase of Gd-EOB-DTPA-enhanced MRI at 1.5 T. Acta Radiol 2018; 59: 509-516.

23. Shimamoto D, Nishie A, Asayama Y, Ushijima Y, Takayama Y, Fujita N, Shirabe K, Hida T, Kubo Y, Honda H MR prediction of liver function and pathology using Gd-EOB-DTPA: effect of liver volume consideration. Biomed Res Int 2015; 2015: 141853.

24. Nojiri S, Kusakabe A, Fujiwara K, Shinkai N, Matsuura K, Iio E, Miyaki T, Joh T. Noninvasive evaluation of hepatic fibrosis in hepatitis $\mathrm{C}$ virus-infected patients using ethoxybenzyl-magnetic resonance imaging. J Gastroenterol Hepatol 2013; 28: 1032-1039.

25. Jang HJ, Min JH, Lee JE, Shin KS, Kim KH, Choi SY. Assessment of liver fibrosis with gadoxetic acid-enhanced MRI: comparisons with transient elastography, ElastPQ and serologic fibrosis markers. Abdom Radiol 2019; 44: 2769-2780.

26. Child CG, Turcotte JG. Surgery and portal hypertension. Major Probl Clin Surg 1964; 1: 1-85.

27. Tsoris A, Marlar CA. Use of the child pugh score in liver disease. 2020 May 17. In: StatPearls [Internet]. Treasure Island (FL): StatPearls Publishing; 2020 Jan-. PMID: 31194448

28. Han D, Liu J, Jin E, He W. Liver assessment using Gd-EOB-DTPA-enhanced magnetic resonance imaging in primary biliary cholangitis patients. Jpn J Radiol 2019; 37: 412419.

29. Okada M, Ishii K, Numata K, Hyodo T, Kumano S, Kitano M, Kudo M, Murakami T. Can the biliary enhancement of Gd-EOB-DTPA predict the degree of liver function? Hepatobiliary Pancreat Dis Int 2012; 11: 307-313.

30. Liang M, Zhao J, Xie B, Li C, Yin X, Cheng L, Wang J, Zhang L. MR liver imaging with Gd-EOB-DTPA: the need for different delay times of the hepatobiliary phase in patients with different liver function. Eur J Radiol 2016; 85: 546-552.

31. Zizka J, Klzo L, Ferda J, Mrklovský M, Bukac J. Dynamic and delayed contrast enhancement in upper abdominal MRI studies: comparison of gadoxetic acid and gadobutrol. Eur J Radiol 2007; 62: 186-191.

32. Ringe KI, Husarik DB, Sirlin CB, Merkle EM. Gadoxetate disodium-enhanced MRI of the liver: part 1, protocol optimization and lesion appearance in the noncirrhotic liver. AJR Am J Roentgenol 2010; 195: 13-28.

33. Chen BB, Hsu CY, Yu CW, Wei SY, Kao JH, Lee HS, Shih TT. Clinical and histologic implications of delayed hepatobiliary enhancement on magnetic resonance imaging with gadolinium ethoxybenzyl diethylenetriaminepentaacetic acid. Invest Radiol 2012; 47: 649-655.

34. Kwee TC, Takahara T, Niwa T, Ivancevic MK, Herigault G, Van Cauteren M, Luijten PR. Influence of cardiac motion on diffusion-weighted magnetic resonance imaging of the liver. MAGMA 2009; 22: 319-325.

\section{Address for correspondence:}

\section{Jakub Jaskólski}

Department of Diagnostic Imaging

Voivodeship Hospital

Kielce, Poland

Phone: +48 513037508

E-mail: jakub.jaskolski91@gmail.com 